\title{
Fritz Peter Knapp In Search of the lost French 'Ur- Renart'
}

\section{Paola Cifarelli}

\section{Q OpenEdition \\ 1 Journals}

\section{Édition électronique}

URL : https://journals.openedition.org/studifrancesi/4576

DOI : 10.4000/studifrancesi.4576

ISSN : 2421-5856

Éditeur

Rosenberg \& Sellier

\section{Édition imprimée}

Date de publication : 1 avril 2012

Pagination : 117

ISSN : 0039-2944

\section{Référence électronique}

Paola Cifarelli, « Fritz Peter Knapp In Search of the lost French 'Ur-Renart'», Studi Francesi [En ligne], 166 ( | LVI) | 2012, mis en ligne le 30 novembre 2015, consulté le 19 novembre 2021. URL : http:// journals.openedition.org/studifrancesi/4576 ; DOI : https://doi.org/10.4000/studifrancesi.4576

Ce document a été généré automatiquement le 19 novembre 2021.

\section{(c) (i) (9)}

Studi Francesi è distribuita con Licenza Creative Commons Attribuzione - Non commerciale - Non opere derivate 4.0 Internazionale. 


\title{
Fritz Peter Knapp In Search of the lost French 'Ur-Renart'
}

\author{
Paola Cifarelli
}

\section{RÉFÉRENCE}

Fritz Peter Knapp, In Search of the lost French 'Ur-Renart', «Reinardus», 22, 2010, pp. 65-75.

1 L'A. revient sur les questions concernant l'origine des histoires de Renart et met en parallèle les variantes de la branche I et de la branche $\mathrm{V}$ avec le texte néerlandais de Van den vos Reynaerde, composé avant la réalisation des plus anciens manuscrits conservés du texte ancien français, puis avec le texte allemand de Reinhart Fuchs, dans le but de relancer l'hypothèse d'une transmission orale des aventures renardiennes. 